\title{
Psychodynamic incidents in teaching: Researching relational aspects of classroom practice
}

\author{
Ambrose Hogan* - UCL Institute of Education, UK
}

\begin{abstract}
For those working in the relatively new field of psychosocial studies, the action of psychodynamic phenomena in day-to-day life is uncontroversial as these phenomena are at work both in clinical settings and in normal life outside the clinical frame. If this is indeed the case, then they must also be at play in everyday classrooms. But to what degree, and to what effect - and how can we create data exploring these issues? This article is the result of a doctoral study that looks at these issues. It explores the methodological and ethical complexities around investigating intimate psychodynamic events experienced in the public context of the school; it presents some extracts from the data constructed, exploring the intersection between narrative methods, autoethnography and psychoanalytic inquiry. This article concludes with some suggestions as to ways that teachers and researchers might continue to explore such psychodynamic incidents.
\end{abstract}

Keywords: teaching, psychosocial, Jungian, narrative, autoethnography

\section{Background and context}

This article reports on innovative data construction approaches that emerged during a research project into the psychodynamic aspects of teaching and learning. The project was conducted between 2013 and 2018, and developed from my experiences in secondary teaching, higher education and Jungian analysis. The project thus sought to explore the boundaries between psychodynamic clinical practice and what happens in teaching.

The term 'psychodynamic' can be understood as follows: 'psychodynamic' is a term applied to a model of counselling and psychotherapy whose theory and clinical practice broadly derive from psychoanalysis. In common with psychoanalysis, psychodynamic work understands someone's present in the context of their past and its influence on their development. It focuses particularly on relationship, including the way a client forms relationship with the counsellor, and places importance on an awareness of the significant part played by the unconscious and the involuntary in our sense of ourselves and our sense of other people. (Baker, 2006: 173)

The connections between psychoanalysis and teaching have periodically been probed since psychoanalysis first emerged as a way of thinking about personal growth and development (Ascher, 2005). Deborah Britzman (2003, 2015), Alice Pitt (Pitt and Brushwood Rose, 2007), Claudia Lapping (Lapping and Glynos, 2018) and Tamara Bibby 
(2011) have all explored how psychoanalytic theories might be applied to qualitative data about teaching or classrooms. A smaller number of writers have written about the experience of these processes at a subjective - or intersubjective - level: Clio Stearns (2013, 2016), Andrew Murray (2016) and John Tieman (2007) have all written about their personal experiences in school, informed by psychoanalytic thinking of one kind or another.

My teaching practice convinced me that aspects of what I did as a secondary school teacher were psychodynamic. What kept surfacing for me was the sense that the dialogic qualities of teaching and learning mirrored the dynamic alchemy that was experienced in the consulting room. Children and young people sought a meaningful connection with their teacher; these children became part of the teacher's imaginative world, were discussed with colleagues, thought about outside school. Often, in learning situations, the unspoken, the unthought, the unthinkable was a force.

My particular interest is in exploring psychodynamic phenomena that are fundamental to clinical psychotherapeutic processes, but which are likely to be problematic for teachers even to imagine: I'm thinking here particularly of such things as desire, hate, fantasy and love. The methodological question I was faced with was, therefore, how, ethically, to create robust and persuasive data that captured these phenomena without risking the safety of my participants. This article presents extracts from the two forms of data that emerged from the project: co-authored narrative and autoethnography.

\section{An ethical frame}

I spent years planning - rather than doing - this project, partly because of my awareness of my own psychic material, the complexity of my motivations and my concern about how this might 'infect' respondents or collaborating participants.

These concerns led me to think about giving boundaries to my study with what, for want of a better vocabulary, might be labelled a supervisory frame, an ethical frame or a methodological frame: this would provide scrutiny of my work and some sort of containment. In speaking of a frame, I am borrowing a concept from clinical practice. The analytic frame as defined by Killick (2014) refers to the process and behaviours that structure and protect clinical interactions, defining the boundaries and edges of the clinic, setting contexts and behaviours. As Killick describes it, the frame may be the expression of this deep theoretical understanding, but it is enacted through details that intrude into the analytic relationship and create boundaries: bills for payment, starts and ends of sessions, and an analytic detachment paradoxically rooted in compassion. A methodological frame might allow for the same space in which new knowledge could be created in the interaction between the author/researcher and co-researchers, and would be enabled by the maintenance of boundaries framing the process.

Julie Walsh has commented on her experience of the frame in university tutorials (Walsh, 2012), and in her case of the need in those situations to break it because of the power of the forces operating inside it. The transference (of ideas and feelings from the patient to the therapist) and its allied psychodynamic forces are essential to that which happens within the frame - the transformation, change and growth towards better knowledge and understanding. Though coming from a Freudian tradition, Walsh's writing speaks to what some Jungians acknowledge as the shamanistic qualities of the psychodynamic relationship within the frame, of how powerful forces can be enabled when normal human exchanges take place framed by certain power structures. These things are not just normal life, they are elevated, extracted from normal interactions, 
creating special spaces out of time and normality in which particular things occur: change, learning, relationships, numinous memories.

These issues, combined with epistemological concerns about how someone who was not a psychotherapist might have a hope of talking legitimately about psychodynamic forces, led me to combine elements of a psychoanalytic training with the study. Thus, I reengaged with personal therapy, attended an infant observation seminar for nine months, then took the year-long Foundations Course at the Jungian Society of Analytical Psychology, followed, for two years, by their Jungian Processes Experiential Group. I have continued this aspect of my research, volunteering in hospital chaplaincy and for a mental health charity, where I have been undertaking supervised therapeutic work.

\section{Co-authored narrative}

I was keen to construct data with other teachers, in an attempt to explore whether my experiences might be familiar to others (and to show that I was something more than an outlier or a dataset of one).

Several factors led me away from conventional methods of creating data, such as the qualitative research interview, in which a respondent's words are subjected to the researcher's interpretation and exegesis. From a feminist perspective, Rosalind Edwards and Melanie Mauthner (2002) warn us about the power relationships that are implicit in certain research methods. They ask us to question the 'cognitive authority' of the researcher, who has been endowed with the official status that allows them to decide what is and what is not knowledge. Svend Brinkmann and Steinar Kvale (2005: 164-5) offer a coruscating critique of new conventions of qualitative research, in which researchers opt unthinkingly - one might say unconsciously - for qualitative interviews, without considering five key problems: the asymmetrical power relations in the interview; the one-way dialogue of the interview; the instrumental nature of the exchange; the manipulative quality of the dialogue; and the interviewer's monopoly of interpretation. For them, the interview has to be seen within the logic of contemporary capitalism, in which the individualism of the interview fits the logic of the post-industrial consumerist market; this critical approach to qualitative research is something that Lather (1991: 72) sees as a transformative social and political project.

This debate mirrors a similar question that surfaces in psychoanalytic discussions of clinical method. In his exploration of 'the Practical Use of Dream Analysis', Jung (1954: 146-7) cautions against 'one-sided interpretation[s]', and encourages analyst and analysand to approach the unconscious as partners in a hermeneutic process that will change both of them. His writing here offers a Jungian approach to the co-construction of knowledge. This collaborative method, offering a degree of humility in the face of the unconscious, builds on the radically inductive quality of Jungian psychology, which has its roots in a direct experience of the unconscious (as charted in Jung's Red Book, finally published in 2009), rather than a theorization about it (Jung, 2009).

Among the readings on the teacher education programme I work on is a co-authored narrative by Jerry Rosiek and Zachary Dean Sconiers (Sconiers and Rosiek, 2000). This introduced me to narrative as a form of inquiry, and, in particular, sonata form. This is a co-authored approach to narrative, resulting in stories of experiences in school that are composed of a series of interlocking vignettes (Chang and Rosiek, 2003, Mitchell and Rosiek, 2006, Petrovic and Rosiek, 2003). 
This form of co-authorship, approached with a sincere, mutual commitment to co-construction, diffuses many ethical and methodological criticisms: the researcher adopts a humility in the face of the unknown; both researcher and respondent become co-authors with shared cognitive authority, rejecting the simple imbalance of a conventional interview; the dialogue becomes a mutual exchange of draft and redraft; instrumentality is rejected in favour of process and teleological emergence; the manipulative quality of conventional interviewing is replaced by an ethic of openness and mutuality; the interviewer's monopoly of interpretation is replaced by shared analysis that takes place over mutually constructed redrafts; a capitalist logic of consumption is replaced by post-industrial production.

So it was that 'Rhiannon' and I worked together through the autumn of 2015 and spring of 2016 to construct a narrative about what was going on at her school. The interviews were audio-recorded, and I brought back material from one meeting to the next for us to explore and think about. Eventually, a single story emerged the narration of a particular critical incident, which I then wrote up into a short story. At Rhiannon's request, we opted for a third-person narration: Rhiannon's own words, taken from the transcripts of our conversations, form the basis of the story (a technique used by many contemporary playwrights).

An extract of what we wrote together follows. It's not perfect, and for some its style will be odd (though readers familiar with either Critical Race Theory or some experiments in autoethnography might not be surprised by the form). But it captures something both of what Rhiannon said and how she responded to my challenge to explore how the psychodynamic might be at play in her school.

\section{An extract from Rhiannon's story}

It must have been the Wednesday just after half term, and a rumour had been going around school that some of the girls were going to make trouble outside school - some said there were weapons involved.

The first Rhiannon learnt was when she asked the other children about the empty desks in her class that afternoon. Where was Tasha? That empty chair was an annoying gap: Tasha had proved to be a handy child to have in class, and was always coming up with good ideas about Macbeth. The ironies.

On the way back to the staff room after the lesson, there was one of them, sullen and slumped over a desk, outside Marika's office - and another kid quietly working through some maths problems on the first floor near the staff room.

The other four were 'held' outside offices spread around the school.

This left the head of year with a bit of a problem. Having six kids from your year internally suspended because they might have been planning an armed attack later that week is hardly bread-and-butter for a head of year in even the roughest comprehensive: anyone would expect them to get a bit of top-cover from senior management. Nothing, however, was doing.

Tracey (one of Rhiannon's colleagues) had found Jane, the head of year, at the end of break on the Thursday, and she was near to tears. 
'She's had about as much as she can cope with.' Tracey leaned in, over a cup of coffee in Rhiannon's office. 'There are six of these kids, one outside her office, one outside Marika's and another outside John's. There are another two up at the other end. And the Deputy Head wasn't there, so she appealed to Marika who's stomping around saying 'no, no', she didn't think she could have anything to do with it ... Jane feels very unsupported - she was nearly in tears - a PE teacher, in tears! I've never seen anything like it.'

Rhiannon caught Jane at the end of the day, and got her to talk. 'No one's really dealing with it, and no one is helping me deal with it at all: there are these kids who've been taken out of lessons for two days, and there might be knives in this. Who knows, the police might need to be involved. And all Marika can do is have a strop when I ask her for help; and everyone else - all the other SLT [senior leadership team] - are just avoiding it, not answering my emails or backing me up. I can't do this on my own, it's not my job, it's too big - six kids, knives, exclusions: even if they are in my year, if I did anything, it would be way above my pay grade'.

Marika's refusal to do anything was the key to it really, thought Rhiannon to herself: apparently, she'd just strode past the head of year's office, throwing a 'I can't do this now' at Jane's appeal for help. That must have been one of the things that pushed Jane to the edge of tears. But what was Marika getting at?? It seemed so emotional a reaction, as if she were either in an uncontrolled strop, or maybe making some sort of point, like 'it's not going to be my job if it's not anybody else's job'. The thing about Marika, thought Rhiannon, pouring herself another cup of tea, is that she works very well when guided, so long as there's someone senior to her who'll tell her what to do: then she'll do it. And she's very good at what she does she's very good at dealing with troublesome children, and isolating them, or whatever, but if no one tells her what to do, if no one gives her orders $\ldots$ and this, this flat rejection to help, this was an emotional response, 'I'm not dealing with it, if the ones above me aren't dealing with it'. As if she were saying 'no one else can be bothered to do it, I'm not going to bother to do it'. Which seemed to Rhiannon quite strange, really, for a grown-up. 'I can't deal with this now.' She was making some sort of stance that she wasn't prepared to do the work if other people weren't ... or did she mean that she wasn't coping, either, and that she needed help - but didn't know how to ask??

Rhiannon and I spent a significant amount of time talking through what might constitute a psychoanalytic approach to what happens in schools, and this last paragraph is Rhiannon's analysis of the incident (largely in Rhiannon's own, edited, words), and represents her take on this challenge I presented to us both: the Assistant Head ('Marika') acting out like a teenager, because of a failure of senior staff to engage with a particular problem. One might add from a psychoanalytic perspective that what appears to be absent here was some sort of containment structure in which near existential anxieties might be 'held', examined, understood and thus robbed of their damaging emotive possibilities. 


\section{A turn to autoethnography}

This project was conducted as part of a doctoral programme of study in which supervision was not unproblematic: indeed, it proved sufficiently complex to form the basis of extended writing in the thesis itself. In summary, one supervisor left the institution and her replacement didn't like the co-authored narrative approach; several months later, mutual dissatisfaction with the process resulted in my continuing the research with a third supervisor. By that point, it was felt that more than enough data had been generated; what was needed was a methodological framework to organize all the material that had emerged from so many years of teaching and research: autoethnography offered that overarching solution.

Autoethnography (as surveyed by Pat Sikes in her impressive multi-volume handbook) offers a methodological approach that is flexible and pragmatic as regards the style and form of writing adopted: the key element is that the writer becomes the source of ethnographic material and the data generated have more than simply personal or artistic value, being concerned with 'the advancement of social knowledge' (Sikes, 2013: xxviii).

The use of autoethnography in my work emerged out of a methodological crisis: despite all my care and caution, and the scrupulous attention to ethical boundaries, the project was teetering, at risk of being overwhelmed by its own engagement with the unconscious. Autoethnography initially offered a space to explain what had happened, but in that process the method opened up other, richer, opportunities in which it would be possible to create data about the psychodynamic issues that had first prompted me to engage in the research.

What I offer in the next section is an extended extract from some authoethnographic material in which I consider my relationship with one of my former pupils. It forms an element in my doctoral thesis, and was prompted by the arrival of an email in November 2013: in that year, I received four emails from former pupils, all of which are used as starting points for similar explorations about psychodynamic material in the manner that the following example illustrates.

It is relevant (but cannot be fully explored here given the restrictions of space) that the school in which the incidents described took place was a single-sex girls' comprehensive church school; I am male.

\section{An email}

In a series of synchronicities, during the year that I started the project, I received three emails from former pupils. One came from a woman in her mid-twenties:

Hi Mr Hogan, Was randomly on the internet and searched your name. Im glad i found you as ive often thought of you and hoped one day id have the chance to thank you for being such an amazing and supportful teacher. You were always so patient and supportive with me. You helped me through a very difficult time in my life. Unfortunatly at the time i didnt feel confident enough to report the sexual abuse that $\mathrm{i}$ was being subjected to during my years at school and as a result it was a very chaotic and disruptive time for me however i eventually dealt with my demons and after years of hard work and therapy i am now a calm, well balanced, happy mother. Thank you again for making a bad time more bareable. November 2013. 
If I wanted to use her real name, I guess about a hundred teachers would recognize it, and remember her decades after teaching her: 'Tara' was one of those school characters who form the legends of PGCE behaviour management and pastoral care lectures - one of the many who you never forget - and I taught her from age 12 to when she left school at 16.

When I first read the email above, I was touched and moved, to the point of tears, and for so many reasons. It seemed to me that she was saying that only after leaving school had she been able to name the abuse she'd experienced, and I'd helped in some way during that period when the unnamed abuse was taking place. On reflection, what I now see is that there was a connection between us because of our shared traumatic personal histories, but both of us were only really able to understand that link outside of the context of the school - and yet the link was created in the context of the school: for both of us, that environment was in some way 'containing'.

My recollections are that when I first started teaching her class, I was warned that she would be a challenge; I also recall that (because of the way the school in question managed behaviour) for large chunks of Year 9, and on occasions in Years 10 and 11, Tara wasn't in my lessons (always because of things that happened elsewhere). For whatever reason, I know I worked quite hard to keep her in the classroom, though this wasn't always easy, and the knowledge of what she disclosed in her email changes how I think and feel about so many of the anecdotes and incidents I used to tell about her.

In Year 8, in the first year of our relationship, I remember keeping her behind on one occasion because of something she'd said or done in class, which had gone over one line or another, and asking 'Tara, do you know what a boundary is?' 'Yeh-heees', she replied (in a bored, bored voice); merely using the right vocabulary (a word I'd learnt from personal therapy) re-established my authority and reminded her of what was and was not appropriate in the classroom. At the time, I felt quite proud of myself: I'd reasserted my professional identity without losing my temper or excluding the child; but now, thinking back on it, with all the things that have happened since, what I notice is how my aspiration to 'professionalism' and the 'maintenance of boundaries' seems a defensive manoeuvre, protecting me from engaging with the possibilities of what other boundaries in Tara's life might have been broken, or damaged irreparably, of what it was she was communicating, consciously or unconsciously, through the symbols of behaviour.

In that same year, during a quiet moment in class (I think we were doing some whole-class reading), I noticed her fiddling with her skirt (she sat immediately in front of me); the fidgeting continued - it was clear that her hand was in her skirt, at the front. I kept my cool, trying not to think about what might actually be going on, with her hand, under her skirt ... eventually, she pulled out a Pritt Stick. That was the day I learnt that girls' uniform skirts have pockets in the front, and I used to tell that story for laughs, timing it so that the last thing to be mentioned is the Pritt Stick, and getting a laugh, usually, because of its phallic quality. But it's not so funny now, because (as I recall reading in an NUT [National Union of Teachers] briefing note a short while ago) all behaviour is a form of communication, and I am troubled by what may have lain beneath this act, what the stick of glue down the front of her skirt may really have meant.

In my second year as a qualified teacher, Tara was in Year 9; this was the period when she began to spend so much of the time out of lessons, sitting instead in 'isolation' outside the Head Teacher's office, rather than with me and my teaching colleagues. She was with us again, and had - as I recall - only recently returned from a stint of 'internal exclusion'. The class and I were again doing some whole-class reading, probably of Animal Farm or of some photocopied text in preparation for the SATs, and I suddenly 
smelt burning. [...] Tara instantly stumbled into life, apologising profusely, laughing at her own foolishness, slapping her canvas army surplus bag to douse the wisps of smoke, and explaining that she'd just been idly playing with her lighter (hidden in the bag, lying on her desk), and it had started to smoulder. It was out now, she reassured us. I looked over, and saw that to be the case. There was what screenwriters call 'a beat'. I remember thinking - quickly, simultaneously, and only partly with words (as one does in these situations) - 'so she has a lighter; so she smokes, but I've not caught her smoking, she's just got back into class, they're all waiting with baited breath to see how I deal with this; I think they want to keep her here, too; am I really going to send her out again? She's apologised; we all fidget'. 'OK' I said, 'let's move on'. I felt the class relax. I thought I'd done the right thing.

I resolved to be stricter about keeping bags off the table, and sharper-eyed about how children hide prohibited activities in camouflage such as bags and blazers.

I now find myself looking at all this, and wondering why, instead of fidgeting and 'attention seeking' or bravado ('look everyone, I'm a rebel, I smoke'), I didn't see 'borderline fire-setting', and all the potential pathology that goes with that possibility of pyromania. Part of the reason is that we all knew she had 'issues': Tara was known to social services, on every list you could imagine, and had the personal attentions on a weekly basis of the Head, Deputy Heads and nominated child protection officer. Thinking about it now, I am again struck by how these processes operate as Menzies Lyth (1990) showed happens in nursing not just to ensure care and protect children, but to protect us from all the things that happen in teaching: all the other 'stuff' (the behaviour management procedures, the exclusion, the threat of exclusion) stopped me asking at the time, why did this happen? what does it mean? because they trumped other teacher ways of thinking, including that of the psychoanalyticallyinformed teacher.

There was another element to this incident: the professional context in which I was working was complex. Sometimes school leaders talked of the importance of teachers' professional judgement, of how effective teachers dealt with behaviour issues themselves in their own classrooms, rather than resorting to management to sort things out. And sometimes school management attempted 'zero tolerance' policies; more often than not, and this is certainly what happened to Tara, once a child became 'an issue' she was given no quarter. This punitive approach to behaviour changed the way I (and many of my colleagues) behaved - I found myself trying to protect her from further exclusion, rather than report what had happened. It was a position I adopted through feeling, rather than thinking - it was not a considered, philosophical position, but something rather that I sensed to be the right course of action to take. Had I reported the incident with the lighter, would one of my colleagues seen it as fire-setting? Would they have thought about the symbolic significance of this behaviour, and its possible connection with abuse? Would it have prompted someone to ask the right question? Had that question not been asked by one of the numerous professionals involved in her life already? What I now see to have been taking place was an attempt - an unconscious attempt - to communicate with me.

In their Y11, Tara's class and I read 1984: one of the trickier elements of that novel are Winston Smith's fantasies of sexual violence:

Suddenly, by the sort of violent effort with which one wrenches one's head away from the pillow in a nightmare, Winston succeeded in transferring his hatred from the face on the screen to the dark-haired girl behind him. Vivid, beautiful hallucinations flashed through his mind. He would flog 
her to death with a rubber truncheon. He would tie her naked to a stake and shoot her full of arrows like Saint Sebastian. He would ravish her and cut her throat at the moment of climax. Better than before, moreover, he realized why it was that he hated her. He hated her because she was young and pretty and sexless, because he wanted to go to bed with her and would never do so, because round her sweet supple waist, which seemed to ask you to encircle it with your arm, there was only the odious scarlet sash, aggressive symbol of chastity. (Orwell, 2004)

It was either when I dealt with this particular and challenging (but critically rewarding) element of the book, or during a class discussion around that time, that Tara launched into a wild anti-feminist speech, a performance in which she seemed to relish developing her outsider rôle into a new territory. She often took a leading rôle in our class discussions, but l've forgotten most of the details of her other contributions. Not this one. She began an 'Iron John' defence of masculinity, which became more and more rhetorical, garnering awkward, slightly uncomfortable giggles from some of her classmates (most of whom will have disagreed with her, but didn't choose to take her on) - the room seemed filled with a sense of something disturbed, something only half-understood, most of us unsure whether what we were watching smelt more of madness than genius, of being with something somehow right, and yet somehow wrong. Her peroration concluded initially with a salute to the abstract 'phallus' as I recall, her exact words were, strikingly, 'yes, we salute the phallus' - and then finally with a gesture of respect in my direction, as its concrete representative in the classroom: a matter of both synecdoche and metonym, I now realize. I wish I'd thought of the linguistic points at the time, because instead of taking the opportunity to explore aspects of rhetoric and literary theory, I think I just said 'thank you, Tara', and moved on with the lesson, conscious that I had very nearly lost control. Dealing with it that way, I still had a class. She was 16 by this point and, said by anyone else, such a striking intervention would have been less memorable: risqué, yes, a bit tasteless, yes, but excludable? no: a faux-pas by an over-enthusiastic young person, something they would be embarrassed about later, and something to be forgotten about. But I haven't forgotten it; and looking at it now, it seems to exemplify how psychodynamic processes play in the classroom.

In writing this up, I have been troubled by the question of whether, at an early stage in my teaching career, I made the correct professional judgement in keeping these incidents (which took place over four years) to myself, and whether the effect of so doing was possibly to prevent information getting to the right people who might have been able to put things together and help Tara, thus possibly getting her to report earlier what had been happening to her. Yet it is only now, with all the experience and analysis that I've been through, that I begin to understand what these incidents might have meant, and that these incidents were things that should perhaps have been followed up in some way. Crucially, it only makes sense with her disclosure to me in her email of 2013.

If I bracket off the question of whether or not I did the right thing, what is interesting is what Tara is grateful for, and why she took the trouble to write to her former English teacher so long after the events. To put it in the third person, and acknowledging the influence on this project of the literary form of clinical case studies:

Tara was grateful to her former English teacher for his 'supportive' qualities, and his ability to be 'patient'; she thanked him for him for being someone who helped her 'through a very difficult time' in her life. It appears that 
he and his lessons in some degree offered a containment structure which helped Tara in her struggle to find something positive, appropriate and reasonably consistent in her life. Through tolerating tensions, and allowing Tara space to project some of the symbolic material from her inner world, he provided an alternative parenting structure, neither infantilizing her nor expecting her to be older than her years. This tolerance was not always easy to maintain, and was the product of both experiential learning and professional discipline; it involved holding the frame and allowing Tara space within it to engage in her own forms of experiential learning.

\section{Discussion}

I am sure that not all teachers experience school like this. I recall a seminar some years ago with a group of newly qualified teachers: one in the group had begun to talk about the number of times she was called on by children to listen to their problems and difficulties, or in some way get involved, if only by listening. Another immediately commented that she was never asked to help or listen in that way. After a brief reflective pause, I asked this second teacher if she wanted to be used like that: 'No', she said. It seemed likely that the children had detected some sort of psychodynamic process that the teacher who wanted to help got involved, and the one who chose to stay firmly apart from this particular messiness was never troubled.

Consider this vignette from an article by John Tieman (2013: 100), a teacher working in the USA:

One day I was teaching and the kids were talking, acting out. I tried to shut them up several times, but to no avail. So I put my head in my hand for half a second and said what has become my favourite prayer: 'Lord, you've entrusted me with Your most sacred creation, the children. Now give me the strength, Lord, the strength to stay.'

At which point Kevin looked up at me, looked worried, and said to the class, 'Be cool, everybody. Be cool. Or he's going to leave us just like everyone else leaves us.'

Tieman explains that one of the elements in this situation was his own experience of having been abandoned as a child by his father. Combined with this, the class had had seven teachers in the previous year, and 'only a few of [his] students could name both parents ... half-dozen or so could name neither'. What is at play in this situation, then, is not just the children's experiences of teachers coming and going (which is constructed as abandonment, not just 'moving on'), but also the individual teacher's own experience of being abandoned himself: transferences and counter-transferences suffuse the way that teachers act in the classroom and with children, and how children interact with teachers in their collaborative work to shape the inner and outer worlds of the school.

Clearly, my own needs and insecurities were part of the interactions described previously, and colour my memories, and reconstructions, of them. For this reason, the relationship between the ethics and the method of inquiry in this field of work was subject to very close scrutiny. But a key blurriness surrounds the intersubjective boundary between our conscious and unconscious selves. Consciously, rationally, we know the line that is to be drawn between you and me; but in life, in interpersonal interactions, these lines often become a little fuzzy. Consider the everyday comment such as the one overheard in the street (20 January 2014) 'yes, but he brings it out 
of people! and that's the problem'. The psychodynamic concept of transference challenges the way in which we draw boundaries around ourselves, and can represent a particular challenge for classroom teachers. Looking inside myself, I could see that some of these 'natural archetypal process[es], multi-beamed and multi-directional' (Stein, 2012: 83) embraced not only the clinical phenomena of transference, countertransference, and somatic symptoms, but desire, love and phantasy.

Like Brexit, just because some of us are more sensitive to it (and can articulate what's happening) doesn't mean that it isn't happening to everyone: what Rhiannon's narrative shows is just how powerful psychodynamic forces can be in those situations where they are not being consciously considered, and thus serve to impede and impair rational thought. One of the things that emerges from the autoethnographic data is that I functioned in Tara's world in ways beyond my understanding at the time. I argue that we have a choice: these forces can be left to play unconsciously, and drive us into places and ways of being that we may not want, or they can be worked with to change social realities.

Borrowing Howard Tripp's idea of the Critical Incidents in Teaching (2003), I suggest that it is possible to think about moments such as the ones presented here as 'psychodynamic incidents in teaching'. Unlike Tripp, I argue that these events don't come into being simply because they are thought about: psychodynamic incidents have distinct identities because of their psychological and emotive force. We can, however, only notice them when we create the space to bring them to consciousness. A key aspect of the method adopted here, then, is not only the innovative narrative approaches, but the careful attention to the methodological frame and the psychodynamic training that accompanied the process of research and critical reflection.

A particular problem I am now turning to is how to make this form of learning accessible to wider groups of teachers. Following a suggestion made to me by Sonu Shamdasani, one way forward might be to create 'Balint Groups' along the model devised by Michael Balint and Enid Flora Balint-Edmonds (Balint, 1964) and used by general practitioners and other medical professionals to explore and contain the psychodynamic and emotional aspects of their consultations with patients.

What the experience of this research project has shown me is that my initial caution was justified. Yes, psychodynamic forces are at play in schools - they are powerful and worthy of further investigation - but their exploration touches on elements of our personality and relationships that are deeply held, and at times deeply guarded. Their investigation needs to be carefully framed and carefully undertaken.

\section{Acknowledgements}

I am grateful to 'Rhiannon' and to my former pupils for their contributions to this project. Revd Professor Michael Reiss of the UCL Institute of Education has been particularly helpful both in supervising my PhD and in the preparation of this manuscript.

\section{Notes on the contributor}

Ambrose Hogan works at the UCL Institute of Education in master's level CPD for Teachers and Initial Teacher Education; he is a secondary teacher of English and Drama, and a Fellow of the Chartered College of Teaching. 


\section{References}

Ascher, C. (2005) 'The force of ideas'. History of Education, 34 (3), 277-93.

Baker, A. (2006) 'What else do students need? A psychodynamic reflection on students' need for support from staff at university'. Active Learning in Higher Education, 7 (2), 171-83.

Balint, M. (1964) The Doctor, His Patient and the Illness. London: Longman.

Bibby, T. (2011) Education - An "Impossible Profession"? Psychoanalytic explorations of learning and classrooms. London: Routledge.

Brinkmann, S. and Kvale, S. (2005) 'Confronting the ethics of qualitative research'. Journal of Constructivist Psychology, 18 (2), 157-81.

Britzman, D.P. (2003) After-Education: Anna Freud, Melanie Klein, and psychoanalytic histories of learning. Albany: State University of New York Press.

Britzman, D.P. (2015) A Psychoanalyst in the Classroom: On the human condition in education. Albany: State University of New York Press.

Chang, P.J. and Rosiek, J. (2003) 'Anti-colonialist antinomies in a biology lesson: A sonata-form case study of cultural conflict in a science classroom'. Curriculum Inquiry, 33 (3), 251-90.

Edwards, R. and Mauthner, M. (2002) 'Ethics and feminist research: Theory and practice'. In Mauthner, M., Birch, M., Jessop, J. and Miller, T. (eds) Ethics in Qualitative Research. London: SAGE Publications, 14-31.

Jung, C.G. (1954) The Practice of Psychotherapy: Essays on the psychology of the transference and other subjects. London: Routledge and Kegan Paul.

Jung, C.G. (2009) The Red Book = Liber novus: A reader's edition. New York: W.W. Norton.

Killick, K. (2014) 'Soundless screaming: Psychotic anxiety and analytic containment'. In Kiehl, E. (ed.) Copenhagen 2013: 100 years on: Origins, innovations and controversies. Einsiedeln: Daimon Verlag, 859-66.

Lapping, C. and Glynos, J. (2018) 'Psychical contexts of subjectivity and performative practices of remuneration: Teaching assistants' narratives of work'. Journal of Education Policy, 33 (1), $23-42$.

Lather, P. (1991) Getting Smart: Feminist research and pedagogy with/in the postmodern. New York: Routledge.

Menzies Lyth, I. (1990) 'Social systems as a defence against anxiety: An empirical study of the nursing service in a general hospital'. In Trist, E. and Murray, H. (eds) The Social Engagement of Social Science: A Tavistock anthology: Volume 1: The socio-psychological perspective. Philadelphia: University of Pennsylvania Press, pp. 439-62.

Mitchell, R. and Rosiek, J. (2006) 'Professor as embodied racial signifier: A case study of the significance of race in a university classroom'. Review of Education, Pedagogy, and Cultural Studies, 28 (3-4), 395-409.

Murray, A. (2016) 'Psychoanalytically informed teachers: The need for observational training in education'. Schools: Studies in Education, 13 (2), 294-311.

Orwell, G. (2004) Nineteen Eighty-Four. London: Penguin.

Petrovic, J.E. and Rosiek, J. (2003) 'Disrupting the heteronormative subjectivities of Christian preservice teachers: A Deweyan prolegomenon'. Equity and Excellence in Education, 36 (2), 161-9.

Pitt, A.J. and Brushwood Rose, C. (2007) 'The significance of emotions in teaching and learning: On making emotional significance'. International Journal of Leadership in Education, 10 (4), 327-37.

Sconiers, Z.D. and Rosiek, J.L. (2000) 'Voices inside schools: Historical perspective as an important element of teachers' knowledge: A sonata-form case study of equity issues in a chemistry classroom'. Harvard Educational Review, 70 (3), 370-404.

Sikes, P. (ed.) (2013) Autoethnography. Los Angeles: SAGE Publications.

Stearns, C. (2013) 'Pedagogical reflections on loss'. Schools: Studies in Education, 10 (1), 72-90.

Stearns, C. (2016) 'The use of educational objects'. Pedagogy, Culture and Society, 24 (2), 191-203.

Stein, M. (2012) 'A dangerous method'. In Graf-Nold, A. and Buser, S. (eds) A Discussion about the Film, A Dangerous Method. Asheville, NC: Asheville Jung Centre.

Tieman, J.S. (2007) 'The ghost in the schoolroom: A primer in the lessons of shame'. Schools: Studies in Education, 4 (2), 39-55.

Tieman, J.S. (2013) 'Miss Freud returns to the classroom: Toward psychoanalytic literacy among educators'. Schools: Studies in Education, 10 (1), 91-110.

Tripp, D. (2003) Critical Incidents in Teaching: Developing professional judgement. London: RoutledgeFalmer. 
Walsh, J. (2012) 'Interrupting the frame: Reflective practice in the classroom and the consulting room'. Fifth Psychosocial Studies Network Conference - Knowing and Not Knowing: Thinking psychosocially about learning and resistance to learning. London, 17-18 December.

Wiener, J. (2010) 'Working in and with transference'. In Stein, M. (ed.) Jungian Psychoanalysis: Working in the spirit of C.G. Jung. Chicago: Open Court, 81-93. 